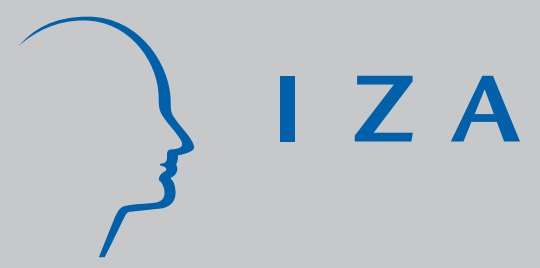

IZA DP No. 730

Innovation and Employment:

Evidence from Italian Microdata

Mariacristina Piva

Marco Vivarelli

February 2003 


\title{
Innovation and Employment: Evidence from Italian Microdata
}

\author{
Mariacristina Piva \\ Catholic University of Milano \\ Marco Vivarelli \\ Catholic University of Milano, ILO \\ and IZA Bonn \\ Discussion Paper No. 730 \\ February 2003
}

\author{
IZA \\ P.O. Box 7240 \\ D-53072 Bonn \\ Germany \\ Tel.: +49-228-3894-0 \\ Fax: +49-228-3894-210 \\ Email: iza@iza.org
}

This Discussion Paper is issued within the framework of IZA's research area Internationalization of Labor Markets. Any opinions expressed here are those of the author(s) and not those of the institute. Research disseminated by IZA may include views on policy, but the institute itself takes no institutional policy positions.

The Institute for the Study of Labor (IZA) in Bonn is a local and virtual international research center and a place of communication between science, politics and business. IZA is an independent, nonprofit limited liability company (Gesellschaft mit beschränkter Haftung) supported by the Deutsche Post AG. The center is associated with the University of Bonn and offers a stimulating research environment through its research networks, research support, and visitors and doctoral programs. IZA engages in (i) original and internationally competitive research in all fields of labor economics, (ii) development of policy concepts, and (iii) dissemination of research results and concepts to the interested public. The current research program deals with (1) mobility and flexibility of labor, (2) internationalization of labor markets, (3) welfare state and labor market, (4) labor markets in transition countries, (5) the future of labor, (6) evaluation of labor market policies and projects and (7) general labor economics.

IZA Discussion Papers often represent preliminary work and are circulated to encourage discussion. Citation of such a paper should account for its provisional character. A revised version may be available on the IZA website (www.iza.org) or directly from the author. 
IZA Discussion Paper No. 730

February 2003

\begin{abstract}
Innovation and Employment: Evidence from Italian Microdata*

The microeconomic empirical literature devoted to the link between innovation and employment tends to suggest that technological change has a positive effect on jobs, at least at the level of the firm. The main purpose of this paper is to see whether this result still holds in a situation where intermediate technologies are implemented mainly through gross innovative investments, as in Italian manufacturing.

Applying GMM-SYS to an employment equation augmented for technology and using a unique longitudinal dataset of 575 Italian manufacturing firms over the period 1992-1997, this paper finds a significant - although small in size - positive relationship between innovation and employment. While the links with sales and wages have the expected signs and turn out to be significant, the job creating impact of innovation proves robust after checking for time, industry, firm's size and geographical fixed effects.
\end{abstract}

JEL Classification: $\quad 033$

Keywords: $\quad$ technology, employment, Italian manufacturing, GMM-SYS

Corresponding author:

Marco Vivarelli

International Policy Group

International Labour Office

4 route des Morillons

1211 Geneve 22

Switzerland

Tel.: +41227998 531

Fax: +41227998 579

Email: vivarelli@ilo.org

\footnotetext{
* We thank Pedro Albarran, Eli Berman, Steve Bond, Eve Caroli, Ari Hyytinen, Petri Rouvinen, Otto Toivanen and John Van Reenen for precious comments and suggestions; usual caveats apply.
} 


\section{Introduction}

Concern about the employment impact of technological change dates back to the origins of the economic thought. Indeed, at the same time as Classical economists were arguing about the so-called "compensation theory" (a term coined by Karl Marx, 1961), English workers were destroying new machines under the charismatic leadership of Ned Ludd in the newly industrialised areas, and of Captain Swing in the countryside (see Hobsbawm, 1968; Hobsbawm and Rudé, 1969). Using Ricardo's words, the "working class opinion" was characterised by the fear of being dismissed because of technological change (see Ricardo, 1951, p. 392), whilst the academic and political debate was mainly dominated by an ex-ante confidence in market compensation for dismissed workers.

From a macroeconomic, aggregate point of view, the direct labour-saving effect of process innovation has to be compared both with the labour-intensive impact of product innovation and with the counterbalancing effects of income and price mechanisms, operating at the firm, sectoral and intersectoral levels. In this view, technological change permits decreasing prices and increasing incomes (profits and wages) and so increasing demand and more employment (for a detailed discussion of these macroeconomic relationships, see Katsoulacos, 1986; Vivarelli, 1995; Spiezia and Vivarelli, 2002). Theoretically, according to the values of crucial parameters such as demand elasticity and the capital/labour elasticity of substitution, compensation mechanisms can fully or partially counterbalance the possible initial labour-saving impact of innovation.

This paper will take a different perspective and will try to assess the relationship between innovation and employment at the level of the firm. Obviously, this change of perspective implies some advantages and some disadvantages. Starting with the latter, microeconomic empirical evidence cannot capture all the sectoral and macroeconomic effects of innovation, hence microeconometric results cannot be generalized. On the one hand, microeconometric evidence fully captures the direct labour-saving effect of innovation at the level of the firm, whilst only partially taking into account all the compensation mechanisms discussed above (in fact, price and income mechanisms operate within the innovating firm but they also leak out in favour of other firms and sectors). This bias makes it more likely that a negative employment impact of innovation will be found, especially when a firm is characterised by the prevalence of process innovation. On the other hand, when dealing only with samples of innovative firms, microeconometric studies tend to neglect the so-called "business stealing" effect, that is the competitive displacements of laggers and non-innovators. This sample bias makes it more likely 
that a positive employment impact of innovation will be found, a result which may be reversed at the sectoral and aggregate levels.

Notwithstanding these possible limitations, the analysis of the link between innovation and employment at the level of the firm permits to carry out a more precise measure of innovating activities, to investigate the employment impact of different forms of innovation directly, and so to test whether a given technological trajectory is intrinsically labour-saving or not. From this point of view, this paper is the first attempt to assess the microeconomic employment impact of innovation in a country - Italy - which is mainly characterised by capital-embodied intermediate technologies. In contrast, previous microeconometric studies of the subject have dealt with more technologically advanced countries where innovation is mainly driven by $R \& D$ expenditures.

For instance, Entorf and Pohlmeier (1990) find a positive employment impact of product innovation - measured with a dummy - in a cross section of 2,276 West German firms in 1984. The positive employment impact of product innovation in West German manufacturing has been confirmed by Smolny (1998) using a panel of 2,405 firms for the period 1980-1992.

Brouwer et al. (1993), using a cross-section of 859 Dutch manufacturing firms, discover an aggregate negative relationship between aggregate $R \& D$ expenditures and employment (while the opposite emerges when only product innovation is considered).

Another panel analysis has been conducted by Greenan and Guellec (1996), using microdata from 15,186 French manufacturing firms over the 1986-1990 period. According to this study, innovating firms - defined according to the outcomes of an innovation survey - create more jobs than non-innovating ones, but the reverse is true at the sectoral level, where the overall effect is negative and only product innovation is job-creating.

Although the employment impact of innovation is not the main object of Doms et al. (1997), the authors find that advanced manufacturing technologies - measured by a set of dummy variables imply higher employment growth in US manufacturing plants over the period 1987-1991.

More controversial results come from Klette and Førre (1998). The authors' database comprises 4,333 Norvegian manufacturing plants over the period 1982-1992; in contrast with previous studies, they do not find any clear-cut positive relationship between net job creation and the R\&D intensity of the examined plants.

As far as the UK is concerned, Blanchflower et al. (1991) analyze 948 establishments in 1984 and they find a positive and significant employment impact of microelectronic technologies after controlling for workplace characteristics such as demand, union density and organizational change. 
Van Reenen (1997) matches the London Stock Exchange database of manufacturing firms with the SPRU innovation database and obtains a panel of 598 firms over the period 1976-1982. The main advantage of the author's panel is that it comprises longitudinal data on new technologies. Running GMM-DIF estimates, the author finds a positive employment impact of innovation and this result is robust after controlling for fixed effects, dynamics and endogeneity.

Blanchflower and Burgess (1998) confirm a positive link between innovation (measured with a dummy) and employment using two different panels of British and Australian establishments; their results are robust after controlling for sectoral fixed effects, size of firm and union density.

As can be seen, on average the (still limited) empirical literature devoted to the link between innovation and employment tends to suggest that technological change has a positive effect on jobs, at least at the level of the firm.

The empirical analysis presented in this work is different from the aforementioned studies in that: 1) it is the first study using Italian microdata and so it gives the opportunity to test whether the positive labour impact of innovation still holds in a situation - such as Italian manufacturing where intermediate technologies are implemented mainly through gross innovative investment; 2) it is the first study, using longitudinal data on innovative activities ${ }^{1}$, to apply a new methodology (GMM-SYS) to the innovation/employment relationship.

The rest of the paper is organized as follows. In Section 2 the econometric model is derived; in Section 3 the unique database used in this study is described and some descriptive statistics are presented; in Section 4 econometric results are presented and commented on; Section 5 is devoted to brief conclusive remarks while some additional technicalities are discussed in the Appendix .

\section{Econometric modelling strategy}

Consider a perfectly competitive firm maximizing its profits under a CES function of the type:

$$
Y=A\left[(\alpha L)^{\rho}+(\beta K)^{\rho}\right]^{1 / \rho}
$$

\footnotetext{
${ }^{1}$ In contrast with most of the previous studies, where technology is often proxied by a dummy or measured by a timeinvariant variable.
} 
where $Y$ is the output, $L$ and $K$ the inputs, $A$ is a potential Hicks-neutral technological change, $\alpha$ and $\beta$ are the parameters measuring the reaction of labour and capital to a technological shock and $0<\rho<1$.

If $W$ represents the cost of labour and $P$ is the output price, profit maximization leads to the following labour demand (in logarithm):

$$
\ln (L)=\ln (Y)-\sigma \ln (W / P)+(\sigma-1) \ln (\alpha)
$$

where $\sigma=1 /(1-\rho)$ is the elasticity of substitution between capital and labour.

The stochastic version of labour demand (2) augmented by including innovation (see Van Reenen, 1997, for a similar approach) for a panel of firms (i) over time (t) is:

$$
l_{i, t}=\beta_{1} y_{i, t}+\beta_{2} w_{i, t}+\beta_{3} i n n_{i, t}+\left(\varepsilon_{i}+v_{i, t}\right) \quad i=1, \ldots, n ; t=1, \ldots, T
$$

where lower case letters indicate natural logarithms, $l$ is labour, $y$ output, $w$ wage, inn innovation, $\varepsilon$ the idiosyncratic individual and time-invariant firm's fixed effect and $v$ the usual error term ${ }^{2}$. It is also possible to add a full set of time dummies to take into account the time dimension.

While specification (3) is static, a dynamic one would be more appropriate for studying the relationship between labour and innovation:

$$
l_{i, t}=\alpha l_{i, t-1}+\beta_{1} y_{i, t}+\beta_{2} w_{i, t}+\beta_{3,1} i n_{i, t}+\beta_{3,2} i_{i n n_{i, t-1}}+\left(\varepsilon_{i}+v_{i, t}\right)
$$

It is well known that this dynamic specification gives rise to some problems. First of all, the lagged dependent variable $l_{i, t-1}$ is - by construction - correlated with the individual fixed effect $\varepsilon_{i}$ transforming the OLS into a biased and inconsistent estimator. A common solution adopted is to use the first difference in order to wipe out the fixed effects ${ }^{3}$ :

$$
\Delta l_{i, t}=\alpha \Delta l_{i, t-1}+\beta_{1} \Delta y_{i, t}+\beta_{2} \Delta w_{i, t}+\beta_{3,1} \Delta i n n_{i, t}+\beta_{3,2} \Delta i n n_{i, t-1}+\Delta v_{i, t}
$$

\footnotetext{
${ }^{2}$ Under the assumption that the disturbances are independent across firms.
} 
Other common problems concern the endogeneity of the lagged dependent variable - the correlation between $\Delta l_{i, t-1}$ and the error term $\Delta v_{i, t}{ }^{4}$ - and the presence of other potentially endogenous variables on the right hand side of equation (5). To solve these problems and to get consistent estimates it is necessary to rely on instrumental variable techniques such as the appropriate GMM estimators (Arellano, 1989; Arellano and Bond, 1991; Arellano and Bover, 1995; Ahn and Schmidt, 1995; Blundell and Bond, 1998)

In particular, Arellano and Bond (1991) define the GMM-DIF estimator (first-differenced GMM); this estimator uses an instrument matrix containing all the instruments for all the regressors where each instrument depends on the specific assumption made about endogeneity, predetermination and exogeneity ${ }^{6}$ of the corresponding instrumented variable.

The GMM-DIF estimator - where standard deviations and t-statistics are based on the covariance matrix consistent with heteroscedasticity problems (see White, 1980) - looses its efficiency when $\alpha$ in equation (4) tends to unity and when the ratio $\sigma_{\varepsilon}^{2} / \sigma_{v}^{2}$ becomes large especially in short panels ${ }^{7}$. More generally, the instruments available for the equations in first differences are likely to be weak when one of these conditions applies ${ }^{8}$. If it is willing to assume that $E\left(\Delta l_{i, t} \varepsilon_{i}\right)=0$ and $E\left(\Delta x_{i, t} \varepsilon_{i}\right)=0$, then it is possible to obtain additional moment conditions. This allows for suitably lagged first differences of the variables to be used as instruments in the equations in levels.

The basic difference is that now we have valid instrumental variables for the untrasformed levels equations. So the GMM-DIF becomes more efficient evolving into the GMM-SYS (system) adding untrasformed level equations instrumented by first difference (see Arellano and Bover, 1995; Blundell and Bond, 1998; Bond, 2002). Also in this case the use of different

\footnotetext{
${ }^{3}$ The first difference (following Anderson and Hsiao, 1981) is better than the within-group estimator especially when the available panel is limited in its time dimension (see also Van Reenen, 1997 and Baltagi, 2001).

${ }^{4}$ The dependance of $\Delta v_{i, t}$ on $v_{i, t-1}$ implies that OLS estimates of $\alpha$ in the first-differenced model are inconsistent.

${ }^{5}$ Under the assumption of no serial correlation of the error term in levels, it is possible to use values in level of the dependent variable lagged two periods back and more as instruments. This implies that the number of instruments grows with the time dimension. The instruments in level permit the use of all the available moment conditions (see Arellano and Bond, 1991; Ahn and Schmidt, 1995). In our case, to have valid instruments, it is necessary that the following two conditions are respected: $E\left(\Delta l_{i, t-1} l_{i, t-s}\right) \neq 0$, if $\mathrm{s} \geq 2$ and $E\left(l_{i, t-2} \Delta v_{i, t}\right)=0$.

${ }^{6}$ If the generic $x_{i, t}$ variable is assumed to be endogenous in the sense that $x_{i, t}$ is correlated with $v_{i, t}$ and earlier shocks, but not with $v_{i, t+1}$ and subsequent shocks, the lagged values $x_{i, t-2-1}, x_{i, t-3}$ and longer lags are valid instrumental variables in the first differenced equations for periods $t=3,4, \ldots, T$. If the variable is assumed to be predetermined in the sense that $x_{i, t}$ may still be correlated with $v_{i, t-1}$ and earlier shocks, then $x_{i, t-1}$ is additionally available as a valid instrument in the first differenced equation for period t. If a much stronger assumption is made, that $x_{i, t}$ is strictly exogenous, then the complete time series of the $x_{i, t}$ or the contemporaneous first difference are valid instrumental variables on each of first-differenced equations (see Bond, 2002).

${ }^{7}$ Thanks are due for the rest of this section to Steve Bond for precious help and suggestions given; usual caveats apply.

${ }^{8}$ As with regard to our data: see next sections and the Appendix.
} 
instruments depends on the assumption made on variables being endogenous, predetermined or exogenous ${ }^{9}$.

GMM-DIF and GMM-SYS estimators are connected because the equations in differences are present in both of them ${ }^{10}$ and their results are generally consistent; yet Blundell and Bond (1998 and 1999) show how the SYS estimator is more efficient than the DIF one if the panel is short in time and if it includes persistent time series (as we will see, our panel is characterised by both these features, see next section and the Appendix). An additional advantage of using the GMM-SYS estimator is that it exploits all information in the levels and difference equations.

In practical terms, the comparison of the GMM-SYS estimator with OLS and within-group estimators may be useful, even if the latters are not optimal: the OLS estimator biases the value of the lagged dependent variable upwards, while the within-group estimator drives the same regressor downwards (as shown in Arellano and Bond (1991) through simulations and empirical applications).

Finally, AR and Sargan tests are necessary tools for judging the validity of the adopted instrumentation (see Arellano and Bond, 1991; Blundell and Bond, 1998) ${ }^{11}$.

\section{Data and descriptive statistics}

The main constraint in the study of the link between innovation and employment is the lack of suitable databases. In this regard, we had the opportunity to build a new database

\footnotetext{
${ }^{9}$ Under the assumption of endogenous $x_{i, t}$ it is necessary to use $\Delta x_{i, t-1}$ as an instrumental variable for the equation in levels because the simple $\Delta x_{i, t}$ is correlated with the error term. If $x_{i, t}$ is predetermined and it is assumed that $\Delta x_{i, t}$ is uncorrelated with the fixed effects, the first difference is a valid instrument for the equation in levels. Finally if $x_{i, t}$ is strictly exogenous, otherwise not correlated with the error term for each $\mathrm{s}$ and $\mathrm{t}$ and $\Delta x_{i, t}$ is not correlated with $\varepsilon_{i}$, it is possible to use the first difference as the instrument for the equations in levels, and if and only if $x_{i, t}$ is not correlated with $\varepsilon_{i}$, the level of the variable can be used as an instrument in the equations in levels.

${ }^{10}$ Generally, the rule linking the two estimators is the following: if $x_{i, t-j}$ is a good instrument for the equation in the first difference, hence $\Delta x_{i, t-(j-1)}$ will be a good instrument for the equation in levels if $\Delta x_{i, t-(j-1)}$ is not correlated with $\varepsilon_{i}$.

${ }^{11}$ The first test measures the serial correlation of the error term, as far as the assumption of absence of the serial correlation of $v_{i, t}$ is essential for the consistency of the estimator. If $v_{i, t}$ is not serially correlated, there must be a negative serial correlation of first level (AR(1)) and no evidence of serial correlation in the second level (AR(2)). Moreover, since there is an overidentified model in the sense that there are more instruments than parameters to be estimated, the validity of the instruments can be tested by means of the Sargan test for overidentified restrictions. Considering the set of instruments used and the need to satisfy the orthogonality conditions, it helps to verify the null hypothesis of joint validity of the instruments. The Sargan test is $\chi^{2}$ distributed under the null with $(\mathrm{p}-\mathrm{k}$ ) degrees of freedom (where $\mathrm{p}$ is the number of instruments and $\mathrm{k}$ is the number of variables in the regression).
} 
derived from the questionnaire surveys developed by the investment bank Mediocredito Centrale (MCC) and addressed to a representative sample of Italian manufacturing firms (with no less than 11 employees). The original MCC database comes from three different questionnaire waves, each one collecting contemporaneous and retrospective data from partially different samples of more than four thousand firms ${ }^{12}$. Apparently very attractive for research purposes, these surveys are however characterised by many drawbacks and inconsistencies and the sample overlapping across waves is unfortunately rather small.

In order to obtain a panel dataset for studying the link between innovation and employment, we excluded the first wave - where no continuous data on innovation were available - and we proceeded to erase obvious inconsistencies, self-contradictory answers and firms subjected to mergers and acquisitions affecting the dynamics of the relevant variables. Merging the second and third waves (1992-1997) and keeping overlapping firms declaring continuos values of employment, cost of labour and sales, we ended up with a panel of 575 manufacturing firms over a 6-year period.

In this panel, innovation is measured through the value of gross innovative investment ${ }^{13}$. This is probably the best proxy for measuring the innovativeness of Italian manufacturing firms. Indeed, embodied technical change is the main innovation channel in Italian manufacturing, which is characterised by: 1) the dominant role of traditional sectors; 2) the prevalence of small and medium enterprises; 3) the diffusion of intermediate technology rather than radical innovation $^{14}$.

It is important to note that the chosen innovation variable must not be seen just as a proxy of process innovation, but rather as a mark of innovativeness (both process and product innovation ${ }^{15}$ ). Indeed, from the MCC questionnaires it turns out that $89.9 \%$ of firms making

\footnotetext{
${ }^{12}$ The first survey covers the 1989-1991 period, the second 1992-1994, the third 1995-1997.

${ }^{13}$ The question in the survey is the following: "Has the firm made gross fixed investments? What is the value? Which percentage of these investments has been devoted to replace old equipment with innovative equipment? Which percentage to the introduction of new innovative equipment?". This question gives the opportunity to compute the total value of gross investments judged innovative by every firm in each year. The variable picks up both the purchasing of new machinery and equipment and any other additional expenditure devoted to support innovation within the firm with the only exception of formal R\&D (see next footnote).

${ }^{14}$ In the second Italian Community Innovation Survey (CIS) covering 1994-1996 (Eurostat, 1999) 46.7\% of the 19,157 innovative firms declared they had innovated through machinery and equipment, meanwhile only $27 \%$ used internal $\mathrm{R} \& \mathrm{D}$ activities, $8.1 \%$ projecting, $7.3 \%$ extra muros $\mathrm{R} \& \mathrm{D}, 5.2 \%$ acquisition of external technologies, $4.1 \%$ marketing and $1.6 \%$ training for innovation (source: ISTAT, 1997, Tab.11). However, the R\&D indicator does not seem adequate to fully represent the innovative efforts of Italian firms, mainly dealing with intermediate embodied technologies rather than $R \& D$. As a consequence, $R \& D$ data in the MCC original database is quite rare and discontinuous, leading to a dramatic reduction in the number of observations.

${ }^{15}$ For an interesting analysis of the relationship between R\&D and process and product innovation, see Parisi $e t$ al., 2002.
} 
innovative investments consider these as a way of improving the quality of existing products, and $36.4 \%$ as a way of introducing new products ${ }^{16}$.

Before presenting the results of the econometric analysis, some descriptive statistics are given in table 1. The sample of 575 firms is divided in three sub-samples according to "innovation continuity" of the firms: in the first group there are 318 firms which innovated during each of the 6 years, in the second group 212 firms which discontinuously innovated during the 6-year period, in the third group 45 firms which didn't innovate ${ }^{17}$.

\section{$<$ TABLE 1>}

As can be seen, the innovative firms - both continuously and occasionally - are larger than the non-innovative ones and they exhibit, on average, better output and employment performances.

\section{Results}

The estimates relative to (5) are presented in table 2. In order to have a comparison between traditional methods and GMM-SYS ${ }^{18}$, first estimates in levels in OLS (1) are carried out, and then by means of the within group estimator $(2)^{19}$. In estimate (1) lagged employment shows a significant positive coefficient, close to though lower than one, thus suggesting the presence of strong persistence. Together with the short time dimension of our panel, this result supports the choice of GMM-SYS rather than GMM-DIF (see also Section 2 and the Appendix $\left.{ }^{20}\right)$.

\footnotetext{
${ }^{16}$ The strict complementarity between process and product innovation in Italian manufacturing is confirmed at the aggregate level: in the second Italian CIS, $60.5 \%$ of innovative firms declared they had carried out both process and product innovation (source: ISTAT, 1997, Tab.4).

${ }^{17}$ The monetary variables are all deflated at 1995 prices (Italian lira) and must be multiplied by 1,000,000.

${ }^{18}$ The GMM-SYS estimates are presented in the one-step version, consistent with possible heteroscedasticity and more reliable than the two-step estimates needed for obtaining the validity tests of the model (see Blundell and Bond, 1998 (section 6.2 and Appendix), Rouvinen, 2002 and Doornik et al., 1999). Standard errors are computed using the asymptotic standard errors, which are obtained using a heteroscedaticity-consistent estimator of the variance-covariace matrix.

${ }^{19}$ Although these estimators are biased, they can still be important indicators of the validity of the estimates in GMM (see Section 2).

${ }^{20}$ Results from the Differenced Sargan test give a further support to the implementation of the GMM-SYS methodology with respect to the GMM-DIF. Differenced Sargan test can be used to test the hypothesis
} 
Sales and wages have the expected signs and are significant. Innovative investments have a positive, small but significant impact on employment during the same period, while the lagged value seems to have a possibly negative effect. This first estimate therefore shows a prevalently positive relationship between innovation and employment, consistently with previous microeconometric studies discussed in Section 1. In column (2) the same estimate is repeated using the within-group estimator where the coefficient of the lagged dependent variable is biased downwards. The signs are all confirmed, including the simultaneous positive relation between innovative investments and employment.

\section{$<$ TABLE 2>}

Taking into account the discussion in Section 2 and the features of our data (see section 3 and the Appendix) we then move to the GMM-SYS (estimate (3) and followings). The assumptions made regarding the variables are the endogeneity of lagged employment and sales, the predetermination of innovative investments and the exogeneity of wages. The choice of these instruments has been the result of a long process of evaluation of the variables and of analysis of alternative methodologies (see the Appendix), leading to the conclusion that the lagged dependent variable and sales are obviously linked with the error component in all periods, innovative investments are predetermined (the alternative assumption of endogeneity is rejected by tests), while wages seem to be exogenous to the model. Hence, in the case of employment and sales, lagged differences are used for the equation in levels, while simultaneous difference is used for innovative investments, and wages are instrumented with the variable itself.

The evidence which emerges supports a positive, significant relation between technological change and employment ${ }^{21}$, while lagged innovative investments result barely significant. The overall long-run elasticity turns out to be 0.0143 . Hence confirming a positive link between innovation and employment.

concerning the validity of some instruments. The full set of instruments under H0 is tested against a strict subset under H1. The test is asymptotically $\chi^{2}$ distributed with degrees of freedom equal to the difference between the usual Sargan test under H0 and H1. In this case, the test is the validity of H0 GMM-SYS against H1 GMM-DIF and the value is 19,63 with 13 degrees of freedom suggesting not to reject the null hypothesis. 
The reliability of the model is confirmed by the coefficient of lagged employment, assuming an intermediate value between those assumed in the estimate in OLS and the within-group (Arellano and Bond, 1991). Furthermore, the two tests of the validity of the estimator indicate both the absence of serial correlation (AR(1) is significantly negative, while $\operatorname{AR}(2)$ is not significant) and the validity of the instruments (the Sargan test does not reject the null hypothesis of joint validity of the instruments).

Table 3 provides some "robustness checks", with the introduction in turn of different groups of dummies which take sectors, size of firm and geographical location into account. In all cases, results are confirmed.

\section{$<$ TABLE 3>}

\section{Conclusions}

Applying GMM-SYS to an employment equation augmented for technology and using a unique longitudinal dataset of 575 Italian manufacturing firms over the period 1992-1997, this paper finds a significant, although small in size, positive relationship between innovation - measured through innovative investments - and employment. While the links with sales and wages have the expected signs and turn out to be significant, the job-creating impact of innovation proves robust after checking for time, industry, size of firm and geographical fixed effects.

While the main finding, that larger innovative investment is associated with higher firm-level employment, is consistent with previous studies, the interpretation of this result has to be very cautious. Taking into account the points raised in Section 1, this microeconomic evidence cannot easily be generalised. A useful extension of this study would be to consider both market selection and technological diffusion at the industry and aggregate levels.

\footnotetext{
${ }^{21}$ A sensitivity regression was also run imposing the level of the innovative investments instead of their first difference. Results are confirmed for all the regressors, also for innovative investments with a coefficient of 0.05 and a standard error of 0.002 (detailed results available from the authors upon request).
} 


\section{$\underline{\text { Appendix }}$}

In this study, GMM-SYS estimates are run following the methodology proposed by Arellano and Bond (1991) and Blundell and Bond (1998) and using the software package DPD 1.00 (Dynamic Panel Data).

In order to test equation (5) econometrically using this approach, some assumptions on the correlation between $x_{i, t}$ (generically the lagged dependent variable and the regressors on the right hand side of the equation) and the error term are made: $x_{i, t}$ can or cannot be correlated with the individual effects, $\varepsilon_{i}$, and for each case there can be a relationship of strict exogeneity, predetermination or endogenenity with $v_{i, t}$.

The assumptions made for the variables derive from the statistical analysis of available data and from some initial estimates which can more easily exclude or assume the hypothesis on the variables themselves.

In the case of wage ( $w$, proxied by the cost of labour per worker in each firm), the exogeneity of the variable is the only acceptable hypothesis in this model. Hence, wage is instrumented by itself, partly due to the construction of the variable and partly to the clear rejection of the Sargan test of the opportunity to use instruments assuming predetermination or endogenity. Sales, $y$, are assumed to be endogenous. To test the validity of this hypothesis, the same model has been estimated considering sales as predetermined and endogenous; the results obtained have been compared by the means of the Sargan tests using the Differenced Sargan (Arellano and Bond, 1991) which compares a model with the total set of instruments in H0 vs. one with a restricted set of instruments in H1 (Rouvinen, 2002). The results, as suspected and suggested in Arellano and Bond (1991), confirm the endogeneity of sales. The value of the predetermined variable against the endogenous variable is not significant at the standard levels.

For innovative investments, inn, the Differenced Sargan suggests that between predetermination and endogeneity, predetermination is slightly better.

The GMM-DIF presents some problems if the time series are strongly persistent and if the time dimension of the panel is so short that the available instruments are only weakly correlated with the variables in differences.

This circumstance has become quite a serious problem, for example in the context of production functions due to persistence of the capital series (Griliches and Mairesse, 1995). In this situation, there are clear efficiency gains from implementing the GMM-SYS estimator. 
The strong persistence of the key variable time series used in this analysis has been tested by measuring the AR(1), obtained from OLS in levels (see Blundell and Bond, 1999):

Table A1: Time persistence of variables in the model

\begin{tabular}{|l|l|}
\hline & AR (1) \\
\hline Employment & $0.99 \quad(0.02)^{* * *}$ \\
\hline Innovative investments & $0.76 \quad(0.08) * * *$ \\
\hline
\end{tabular}

Note: standard errors in brackets $(* * * 1 \%$ significant).

\section{$\underline{\text { References }}$}

- Ahn, S. and Schmidt, P. (1995) Efficient Estimation of Models for Dynamic Panel Data, Journal of Econometrics, vol.68, pp.5-27.

- Anderson, T.W. and Hsiao, C. (1981) Estimation of Dynamic Models with Error Components, Journal of the American Statistical Association, vol.76, pp.598-606.

- Arellano, M. (1989) A Note on the Anderson-Hsiao Estimator for Panel Data, Economics Letters, vol.31, pp.337-341.

- Arellano, M. and Bond, S. (1991) Some Tests of Specification for Panel Data: Monte Carlo Evidence and an Application to Employment Equations, Review of Economic Studies, vol.58, pp.277-297.

- Arellano, M. and Bover, O. (1995) Another Look at the Instrumental Variables Estimation of Error-components Models, Journal of Econometrics, vol.68, pp.29-51.

- Baltagi, B.H. (2001) Econometric Analysis of Panel Data, Chichester: Wiley, $2^{\text {nd }}$ edition.

- Blanchflower, D., Millward, N. and Oswald, A. (1991) Unionisation and Employment Behaviour, Economic Journal, vol.101, pp.815-834.

- Blanchflower, D. and Burgess S.M. (1998) New Technology and Jobs: Comparative Evidence from a Two Country Study, Economics of Innovation and New Technology, vol.5, pp.109-138.

- Blundell, R. and Bond, S. (1998) Initial Conditions and Moment Restrictions in Dynamic Panel Data Models, Journal of Econometrics, vol.87, pp.115-143. 
- Blundell, R. and Bond, S. (1999) GMM Estimation with Persistent Panel Data: an Application to Production Functions, Institute for Fiscal Studies, Working Paper 99/4, London.

- Bond, S. (2002) Dynamic Panel Data Models: A Guide to Micro Data Methods and Practice, Cemmap, Working Paper 09/02, London.

- Brouwer, E., Kleinknecht, A. and Reijnen, J.O.N. (1993) Employment Growth and Innovation at the Firm Level: An Empirical Study, Journal of Evolutionary Economics, vol.3, pp.153-159.

- Doms, M., Dunne, T. and Trotske, K. (1997) Workers, Wages, and Technology, Quarterly Journal of Economics, vol.112, pp.253-289.

- Doornik, J., Arellano, M. e Bond, S. (1999) Panel Data Estimation Using DPD for Ox, www.nuff.ox.ac.uk/Users/Doornik, Oxford.

- Entorf, H. and Pohlmeier, W. (1990) Employment, Innovation and Export Activities, in J.P. Florens (Ed.) Microeconometrics: Surveys and applications, London: Basil Blackwell.

- Eurostat (1999), The Community Innovation Survey 1996 (CIS II), Luxembourg.

- Greenan, N. and Guellec, D. (1996) Technological Innovation and Employment Reallocation, INSEE-DESE, Working Paper G9608, Paris.

- Griliches, Z. and Mairesse, J. (1995) Production Functions: the Search for Identification, NBER Working Paper 5067.

- Hobsbawm, E.J. (1968) Industry and Empire: An Economic History of Britain since 1750, Harmondsworth Middlesex: Penguin Books.

- Hobsbawm, E.J. and Rudé, G. (1969) Captain Swing, London.

- Istat (1997) Statistiche sull'Innovazione Tecnologica 1994-1996, Roma: Istat.

- Katsoulacos, Y.S. (1986) The Employment Effect of Technical Change, Brighton: Wheatsheaf.

- Klette, T.J. and FØrre, S.E. (1998) Innovation and Job Creation in a Small Open Economy: Evidence from Norwegian Manufacturing Plants 1982-92, Economics of Innovation and New Technology, vol. 5, pp.247-272.

- Marx, K. (1961) Capital, Moscow: Foreign Languages Publishing House, first edn 1867.

- Parisi, M.L., Schiantarelli, F. and Sembenelli, A. (2002) Productivity, Innovation Creation and Absorption, and R\&D: Micro Evidence for Italy, Working Paper in Economics, n.526, Boston College. 
- Ricardo, D. (1951) Principles of Political Economy, in P. Sraffa. (Ed.) The Works and Correspondence of David Ricardo, Cambridge: Cambridge University Press, vol. 1, third edn 1821.

- Rouvinen, P. (2002) R\&D-Productivity Dynamics: Causality, Lags, and "Dry-Holes", Journal of Applied Economics, vol. 5, pp.123-156.

- Smolny, W. (1998) Innovations, Prices and Employment: A Theoretical Model and an Empirical Application for West German Manufacturing Firms, Journal of Industrial Economics, vol. 46, pp.359-381.

- Spiezia, V. and Vivarelli, M. (2002) Innovation and Employment: a Critical Survey, in N. Greenan, Y. L'Horty and J. Mairesse, (eds.) Productivity, Inequality and the Digital Economy: a Transatlantic Perspective, Cambridge (Mass.): MIT Press, pp.101-131.

- Van Reenen, J. (1997) Employment and Technological Innovation: Evidence from U.K. Manufacturing Firms, Journal of Labor Economics, vol. 15, pp.255-284.

- Vivarelli, M. (1995) The Economics of Technology and Employment: Theory and Empirical Evidence, Aldershot: Elgar.

- White, H. (1980) A Heteroskedasticity-Consistent Covariance Matrix Estimator and a Direct Test for Heteroskedasticity, Econometrica, vol. 48, pp.817-838. 
Table 1: Descriptive statistics

575 Italian manufacturing firms over the period 1992-1997

\begin{tabular}{|c|c|c|c|c|c|c|c|c|}
\hline & \multicolumn{2}{|c|}{ All firms } & \multicolumn{2}{|c|}{ Innovators } & \multicolumn{2}{|c|}{$\begin{array}{l}\text { Occasional } \\
\text { innovators }\end{array}$} & \multicolumn{2}{|c|}{$\begin{array}{c}\text { Non- } \\
\text { innovators }\end{array}$} \\
\hline & Mean & S.D. & Mean & S.D & Mean & S.D. & Mean & S.D \\
\hline Output & 96196 & 339341 & 86381 & 144344 & 124147 & 528650 & 34010 & 60875 \\
\hline $\begin{array}{l}\text { Average } \\
\text { output growth } \\
(1992-97)\end{array}$ & $5.12 \%$ & 10.21 & $4.54 \%$ & 8.23 & $6.42 \%$ & 12.87 & $3.12 \%$ & 8.35 \\
\hline Employment & 271 & 550 & 291 & 567 & 270 & 567 & 132 & 254 \\
\hline $\begin{array}{l}\text { Average } \\
\text { employment } \\
\text { growth } \\
(1992-97)\end{array}$ & $2.34 \%$ & 8.62 & $2.25 \%$ & 8.54 & $2.67 \%$ & 9.44 & $1.41 \%$ & 3.89 \\
\hline Real wage & 54.13 & 18.74 & 55.22 & 19.32 & 53.42 & 18.65 & 49.74 & 13.47 \\
\hline $\begin{array}{l}\text { Innovative } \\
\text { investments }\end{array}$ & 2351 & 7755 & 2989 & 6628 & 1892 & 9762 & 0 & 0 \\
\hline $\begin{array}{l}\text { Number of } \\
\text { firms }\end{array}$ & \multicolumn{2}{|c|}{575} & \multicolumn{2}{|c|}{318} & \multicolumn{2}{|c|}{212} & \multicolumn{2}{|c|}{45} \\
\hline Observations & \multicolumn{2}{|c|}{3450} & \multicolumn{2}{|c|}{1908} & \multicolumn{2}{|c|}{1272} & \multicolumn{2}{|c|}{270} \\
\hline
\end{tabular}


Table 2: Dependent variable: employment

\begin{tabular}{llcc}
\hline & $\mathbf{( 1 )}$ & $\mathbf{( 2 )}$ & $\mathbf{( 3 )}$ \\
Employment (-1) & OLS & WITHIN & GMM-SYS \\
Sales & $0.93^{* * *}$ & $0.52^{* * *}$ & $0.86^{* * *}$ \\
Wages & $(0.005)$ & $(0.016)$ & $(0.040)$ \\
& $0.06^{* * *}$ & $0.14^{* * *}$ & $0.13^{* * *}$ \\
Innovative investments & $(0.004)$ & $(0.009)$ & $(0.031)$ \\
& $-0.12^{* * *}$ & $-0.35^{* * *}$ & $-0.20^{* * *}$ \\
Innovative investments (-1) & $(0.009)$ & $(0.016)$ & $(0.034)$ \\
& $0.007^{* * *}$ & $0.004^{* * *}$ & $0.005^{* *}$ \\
Constant & $(0.001)$ & $(0.001)$ & $(0.002)$ \\
& $-0.003^{* *}$ & $-0.002^{*}$ & $-0.003^{*}$ \\
Time dummies & $(0.001)$ & $(0.001)$ & $(0.002)$ \\
AR (1) & $0.11^{* * *}$ & & 0.13 \\
AR (2) & $(0.035)$ & & $(0.147)$ \\
Sargan test & & & Yes \\
Observations & Yes & Yes & $-5.76^{* * *}$ \\
\hline Notes: & & & 0.28 \\
\hline
\end{tabular}

\section{Notes:}

- The monetary variables are all expressed in constant prices (base $=1995$ ).

- The OLS and within-group estimates are in levels, while the GMM-SYS estimates combine a system of equations in first differences with a system of equations in levels using as instruments respectively the variables in levels and in first differences.

- In brackets: White-robust standard errors; $*=10 \%$ significant, $* *=5 \%$ significant, $* * *=1 \%$ significant.

- In column (3) lagged employment and sales are considered as endogenous, innovative investments as predetermined, and wages as exogenous.

- $A R(1)$ and $\operatorname{AR}(2)$ are tests - with distribution $\mathrm{N}(0,1)$ - on the serial correlation of residuals.

- The Sargan-test has a $\chi^{2}(43)$ distribution under the null hypothesis of validity of the instruments. 
Table 3: Robustness checks; dependent variable: employment

\begin{tabular}{|c|c|c|c|c|}
\hline & (1) & (2) & (3) & (4) \\
\hline & GMM-SYS & GMM-SYS & GMM-SYS & GMM-SYS \\
\hline Employment (-1) & $(0.037)$ & $(0.037)$ & $(0.039)$ & $(0.043)$ \\
\hline Sales & $(0.027)$ & $(0.029)$ & $(0.030)$ & $(0.032)$ \\
\hline \multirow[t]{2}{*}{ Wages } & $-0.20 * * *$ & $-0.20 * * *$ & $-0.20 * * *$ & $-0.21 * * *$ \\
\hline & $(0.034)$ & $(0.034)$ & $(0.033)$ & $(0.042)$ \\
\hline Innovative investments & $0.005 * *$ & $0.005 * *$ & $0.005 * *$ & $0.005 * *$ \\
\hline Innovative investments $(-1)$ & $(0.002)$ & $(0.002)$ & $(0.002)$ & $(0.002)$ \\
\hline \multirow[t]{2}{*}{ Constant } & 0.16 & 0.14 & 0.19 & 0.16 \\
\hline & $(0.159)$ & $(0.168)$ & $(0.15)$ & $(0.166)$ \\
\hline Sectoral dummies (13 ATECO sectors) & Yes & & & \\
\hline Sectoral dummies (21 ATECO sectors) & & Yes & & \\
\hline Area dummies (4 macro-regions) & & & Yes & \\
\hline $\operatorname{AR}(1)$ & $-5.67 * * *$ & $-5.70 * * *$ & $-5.75 * * *$ & $-5.91 * * *$ \\
\hline AR (2) & 0.32 & 0.32 & 0.29 & 0.25 \\
\hline Sargan test & 54.59 & 55.23 & $55.89 *$ & 54.55 \\
\hline Observations & 2875 & 2875 & 2875 & 2875 \\
\hline
\end{tabular}

\section{Notes:}

- Notes to table 2 also apply to table 3.

- The 4 Italian macro-regions are North-West, North-East, Centre, South and Islands.

- The 5 size classes are in terms of employment : 11-20; 21-50; 51-250; 251-500; $>500$. 


\section{IZA Discussion Papers}

\begin{tabular}{|c|c|c|c|c|}
\hline No. & Author(s) & Title & Area & Date \\
\hline 715 & $\begin{array}{l}\text { E. Fehr } \\
\text { U. Fischbacher } \\
\text { B. von Rosenbladt } \\
\text { J. Schupp } \\
\text { G. G. Wagner }\end{array}$ & $\begin{array}{l}\text { A Nation-Wide Laboratory Examining Trust and } \\
\text { Trustworthiness by Integrating Behavioral } \\
\text { Experiments into Representative Surveys }\end{array}$ & 7 & $02 / 03$ \\
\hline 716 & $\begin{array}{l}\text { M. Rosholm } \\
\text { L. Skipper }\end{array}$ & $\begin{array}{l}\text { Is Labour Market Training a Curse for the } \\
\text { Unemployed? Evidence from a Social } \\
\text { Experiment }\end{array}$ & 6 & $02 / 03$ \\
\hline 717 & $\begin{array}{l}\text { A. Hijzen } \\
\text { H. Görg } \\
\text { R. C. Hine }\end{array}$ & $\begin{array}{l}\text { International Fragmentation and Relative Wages } \\
\text { in the UK }\end{array}$ & 2 & $02 / 03$ \\
\hline 718 & E. Schlicht & Consistency in Organization & 1 & $02 / 03$ \\
\hline 719 & $\begin{array}{l}\text { J. Albrecht } \\
\text { P. Gautier } \\
\text { S. Vroman }\end{array}$ & $\begin{array}{l}\text { Equilibrium Directed Search with Multiple } \\
\text { Applications }\end{array}$ & 3 & $02 / 03$ \\
\hline 720 & T. Palokangas & $\begin{array}{l}\text { Labour Market Regulation, Productivity- } \\
\text { Improving R\&D and Endogenous Growth }\end{array}$ & 3 & $02 / 03$ \\
\hline 721 & $\begin{array}{l}\text { H. Battu } \\
\text { M. Mwale } \\
\text { Y. Zenou }\end{array}$ & $\begin{array}{l}\text { Do Oppositional Identities Reduce Employment } \\
\text { for Ethnic Minorities? }\end{array}$ & 1 & $02 / 03$ \\
\hline 722 & $\begin{array}{l}\text { C. K. Spiess } \\
\text { F. Büchel } \\
\text { G. G. Wagner }\end{array}$ & $\begin{array}{l}\text { Children's School Placement in Germany: Does } \\
\text { Kindergarten Attendance Matter? }\end{array}$ & 6 & $02 / 03$ \\
\hline 723 & $\begin{array}{l}\text { M. Coles } \\
\text { B. Petrongolo }\end{array}$ & $\begin{array}{l}\text { A Test between Unemployment Theories Using } \\
\text { Matching Data }\end{array}$ & 3 & $02 / 03$ \\
\hline 724 & $\begin{array}{l}\text { J. T. Addison } \\
\text { R. Bailey } \\
\text { W. S. Siebert }\end{array}$ & $\begin{array}{l}\text { The Impact of Deunionisation on Earnings } \\
\text { Dispersion Revisited }\end{array}$ & 2 & $02 / 03$ \\
\hline 725 & S. Habermalz & An Examination of Sheepskin Effects Over Time & 1 & $02 / 03$ \\
\hline 726 & S. Habermalz & $\begin{array}{l}\text { Job Matching and the Returns to Educational } \\
\text { Signals }\end{array}$ & 1 & $02 / 03$ \\
\hline 727 & $\begin{array}{l}\text { M. Raiser } \\
\text { M. Schaffer } \\
\text { J. Schuchardt }\end{array}$ & Benchmarking Structural Change in Transition & 4 & $02 / 03$ \\
\hline 728 & $\begin{array}{l}\text { M. Lechner } \\
\text { J. A. Smith }\end{array}$ & What is the Value Added by Caseworkers? & 6 & $02 / 03$ \\
\hline 729 & $\begin{array}{l}\text { A. Voicu } \\
\text { H. Buddelmeyer }\end{array}$ & $\begin{array}{l}\text { Children and Women's Participation Dynamics: } \\
\text { Transitory and Long-Term Effects }\end{array}$ & 3 & $02 / 03$ \\
\hline 730 & $\begin{array}{l}\text { M. Piva } \\
\text { M. Vivarelli }\end{array}$ & $\begin{array}{l}\text { Innovation and Employment: Evidence from } \\
\text { Italian Microdata }\end{array}$ & 2 & $02 / 03$ \\
\hline
\end{tabular}

An updated list of IZA Discussion Papers is available on the center's homepage www.iza.org. 